Talitha Azzahra Putri ${ }^{1}$, Moses Glorino Rumambo Pandin ${ }^{2}$

1

Faculty of Psychology, ${ }^{2}$ Faculty of Humanities,

Airlangga University Surabaya, Indonesia

Airlangga St. No.4 - 6, Airlangga, Gubeng Sub-district, SBY City, East Java 60115

1

talitha.azzahra.putri-2020@psikologi.unair.ac.id; moses.glorino@,fib.unair.ac.id

\title{
Stay Creative and Innovative during the Covid-19 Pandemic
}

Book Title: Staying Creative and Innovative in the Midst of the Covid-19 Pandemic; Author: Hendri Hermawan Adinugraha; Indah Dwi Amilatul A.; Husna N. Ulya; Suwantoro; Zaedun Na'im; Sri Mulyono; Halimatus Sa diyah; Afif Syarifudin Yahya Taufiqur Rohman; Muhammad Khoirul Fikri; Desy Faradisa; Nur Hikmah; Rofiqotul Umah Moh. Muslim; Qonita Irfayani; Sharif Hidayatullah; Armilatun Nasofa; Juwita Rini Novendi Arkham Mubtadi; Setiadi; Siti Nur Azizah; Ismail Marzuki; Dian Arsitades W. Aria Mulyapradana; Mujibul Hakim; Moh. Imam Sufiyanto; Saripah; Ahmad Saefullah; Publisher: PT. Nasya Expanding Management; City of publication: Pekalongan, Central Java; Issue: 1st Printing, January 2021; Number of pages: 237 pages; ISBN: 978-623-6906-46-0

\section{INTRODUCTION}

The Covid-19 pandemic that we are facing today has changed all activities and life in every aspect. Starting from the economic sector and education are all affected. Our view towards Covid-19 is not far from being scary and scary. This causes our physical and psychological conditions to be disrupted so that it hampers all the activities we used to do before this pandemic emerged. Changes in our lifestyles make our mindsets change too, starting from the ideas that we usually spill to being hampered because of this situation. This must be avoided from the mindset of society that we must not be dissolved in the adversity that exists when facing this era. An optimistic mindset is needed to survive and keep thinking creatively and innovatively. Moreover, the millennial generation has a myriad of creative and innovative ideas to be able to advance the Indonesian state in the future while still applying the values contained in Pancasila as a guide for our nation and state. This review is expected to be able to make the millennial generation apply creative and innovative attitudes.

\section{REVIEW}

Covid-19 pandemic has changed all views of the world community, including Indonesia. Covid-19 has been declared as a public health emergency. This interferes with many aspects of life and then affects the behavior and activities in the community. Various efforts that can be made to survive in recent conditions require us to have a creative and innovative mindset. We must learn to open our minds to uphold the values contained in Pancasila that we can apply in everyday life. This book was written to motivate the public, especially the younger generation, to rise from adversity caused by Covid-19. In addition, it provides provisions for individuals to change their mindset to be more optimistic and still think creatively. It is hoped that the millennial generation 
can use it as a reference to become a milestone in the progress of the Indonesian state which requires the millennial generation to be able to work hard in any situation.

This book is addressed to the people of Indonesia who are experiencing a downturn due to this pandemic, especially to people who want to rise and be able to survive in the current situation. The existence of this pandemic has made people's mindsets pessimistic and lazy. Many people who are dissolved in sadness and adversity do not want to change their fate for the better. In fact, in a situation like this, many efforts can be made to remain creative and innovative during the Covid-19 pandemic.

Information presented can help the community in dealing with the pandemic situation completely. The pandemic that has changed people's activities has made people compete to change their lifestyles. The efforts described can serve as a reference for the community to contribute to saving existing sectors, especially the economic and education sectors. The millennial generation, especially students, must continue to have creative and innovative ideas that are shed for the survival of this country.

This review is made to take advantage of the efforts described by the authors in dealing with situations like this. The emergency that befell us is very relevant to the topics discussed in it. Moreover, as a student or millennial generation, you should be able to position yourself to bring change in the conditions of the industrial revolution 4.0 which requires the ability to compete with other countries but must still apply the Pancasila values. It is better to continue to strengthen the existing culture and not to abandon the old culture.

The birth of the book Stay Creative and Innovative in the Middle of the Covid-19 Pandemic is one of the creations and innovations of the Indonesian which is shown to the Indonesian people themselves, their compatriots, and countrymen in dealing with the problems that have existed since the emergence of this virus in Indonesia that can change aspects of our lives. The authors put their ideas into this one book to be able to open the eyes of a generation that is experiencing changes in their activities and lives since the emergence of Covid-19, as well as to meet the needs of ideas and inspire readers to survive.

During the downturn in the face of this era, struggles and hard efforts to survive are needed by people, especially the younger generation as the hope of the nation. Young people must strive to maintain the line of life starting from internal and external factors, lest all sectors in this country become paralyzed and out of control. Living in a creative and innovative view is very much needed. Being creative and innovative in any situation is a form of our efforts to apply existing values.

This pandemic has damaged existing sectors such as the tourism sector, including the economic sector which suffered open losses, especially those experienced by MSME traders. MSMEs are the biggest economic drivers in Indonesia and have been rampant among Indonesian people, from small to large communities. Since the Covid-19 pandemic, MSMEs themselves have spread in Indonesian society to survive. As a result, we have to look for strategic ways so that businesses can continue to run and comply with health protocols.

Hendri and Mila, as two of the authors, tell about one of the MSMEs that can survive in a situation like this, namely 'barokah' banana chips. The strategy carried out by MSMEs uses the promotion technique word of mouth (WoM). In addition, environmental factors support the business because of the nature of harmony that does not fade among the people of the region. The people in the village still adhere to the strong cultural principle of not letting their friends feel down in this pandemic era. Working hand in hand to help each other's efforts following the principles that reflect the 2nd Pancasila precept, namely just and civilized humanity because the 
strategy from the book can influence creating community welfare so that justice will be created during this Covid-19 pandemic.

Covid-19 has made us aware that this virus is actually spreading, and can disturb the psyche also body of Indonesian citizens and outsiders, even from parents to children to teachers and students. Our minds are filled with negative things because of the proliferation of news out there. We have a mindset that our survival has been threatened. The author conveys information that we must do to fight Covid-19 so that the millennial generation is not deterred from continuing doing something from their creative and innovative ideas, such as changing our attitude and perspective to be optimistic, don't let our pessimism dominate us. In addition, increasing spirituality to God Almighty because basically if we have to ask for protection it must be from God bcs he is the one who allows us to stay alive in this pandemic era.

This book finds the things that we can do during this pandemic is a reflection of the application of the Pancasila values, such as getting closer to God, which is the application of the first precept, namely Belief in One God. Our mental health during these times is tested because Covid-19 is the latest source of stress for many people, therefore, a lifestyle that is surrounded by positive things will attract a person to think positively too. The impact that can occur on each individual if he does things to fight Covid-19 is certainly different. Broadly speaking, the author gives an influence on what things we must do to keep an optimistic mindset during the pandemic.

As the nation's next millennial generation during this pandemic, we are required to always be optimistic in doing something, don't get lost in the sadness of living side by side with this virus. Students as one of the golden generations who can provide change experienced problems in the education sector during the quarantine. The responsibility and creativity of students and lecturers must continue to be carried out during this pandemic. Since this pandemic, all learning processes were held with an online system.

This requires teachers and students to continue to be able to follow the learning effectively. Even students usually do Community Service Program (KKN) through an online process, whereas generally, students do community service by directly bringing existing villages. Teachers can position themselves to carry out their duties according to the abilities of their children, but creative and innovative teachers such as using technology media, designing, and using applications according to the material presented can bring changes to their students in taking online lessons without any boredom, lazy, and disorganization.

Employees and workers such as civil servants also experience difficulties and are required to work through technology. In terms of industry, Indonesia's technology should be a superior country because the level of productive age is more than non-productive. The pandemic forced students, students, teachers, lecturers, and other workers to do Work From Home (WFH) to break the Covid-19 chain which continues to experience spikes. One of them is the national civil apparatus which must carry out its duties online.

Civil servants are expected to continue to work professionally without corruption, collusion, and nepotism even though it is done online. The problems arise when implementing WFH, one of them is that workers are not accustomed to working through technology. The problem was handled professionally because the civil apparatus got clear performance targets, clear rewards, and punishments, and provided full support for work facilities. Here the author provides evidence that WFH is not an obstacle for ANS

The author provides accurate and credible facts such as providing evidence of a consistent level of production of 'barokah' banana chips during Covid-19 because the author conducted surveys and interviewed the owner. 
In addition, the author also conveys ideas for ways to improve creative and innovative mindsets during the Covid-19 period, especially for teachers and students, and also the facts about work from home workers because the author himself is a worker and lecturer who experienced something similar so that it makes the reader can be sure about the things conveyed by the author.

references used by the authors also generally use the latest scientific sources and articles about Covid-19, especially the topics raised about Covid-19 and the millennial generation which is being discussed lately. Some sources use references from old and not recent years which can result in changing the facts listed with current conditions.

This book is packaged in a formal style of structure and organization, but several subchapters do not discuss formal things that can be applied in everyday life. some chapters are not continuous with one another, for example chapter one should be continued with chapter 5, chapter 9, and chapter 15 because they both discuss MSMEs and the economic sector that is struggling during the pandemic, preferably a chapter that includes the economic sector is placed at the beginning, the education sector is placed in the middle, then the technology sector is placed last so that the topics are aligned.

The advantage is that it can change the mindset of the Indonesian people, especially the millennial generation, as a provision for the nation to remain optimistic and have a creative and innovative mindset to survive in this Covid-19 pandemic era. The sources presented are also accredited and on average use the latest sources according to the current situation. The facts presented can help the millennial generation to be creative and innovative and not just follow the flow in overcoming Covid-19. It also can be an attraction for the millennial generation who want to survive and be successful in any situation, especially the Covid-19 pandemic situation, by working hard as a reflection of Indonesian cultural values.

Many advantages presented by this book do not rule out the possibility of shortcomings. The drawback is that the topic structure presented is less relevant between chapters, thus making the reader feel confused because it has nothing to do with the next chapter. Some of the references also use old years so that what is conveyed is not necessarily in line with what is currently being experienced. Books that have many pages are a drawback because the current generation tends to choose books that are practical and simple.

I suggest that this book be packaged with topics relevant to the next chapter, such as the economic sector being placed in the first chapters, followed by other sectors. The author should also not use old sources because the theme is Covid-19 which describes the situation currently being faced by the Indonesian people. Readers can read this book so that the view of Covid-19 that paralyzes all our activities is no longer embedded in our brains. In addition, readers can apply ways to keep having creative and innovative ideas that do not fade due to the Covid-19 quarantine.

\section{References}

Adinugraha, HH, A, IDA, Suwantoro, HNU, Na'im, Z., Mulyono, S., Sa'diyah, H., Rohman, ASYT, Fikri, MK, Faradisa, D., Hikmah, N., Muslih, RUM, Irfayani, Q., Hidayatullah, S., Nasofa, A., Mubtadi, JRNA, Setiadi, Azizah, SN, Marzuki, I., Mulyapradana, DAWA, ... Saefullah, A. (2021). Stay Creative and Innovative During the Covid-19 Pandemic (1st ed., Vol. 1). Pekalongan: PT. Nasya Expanding Management. 


\section{Short Biography of the Author}

Dr. Hendri Hermawan Adinugraha, SEI, MSI PNS Lecturer at IAIN Pekalongan. The man who was born in Serang on March 11, 1987, started his lecturer career after graduating from Master of Islamic Studies (Islamic Economics Concentration) at the Islamic University of Indonesia Yogyakarta by becoming a Permanent Lecturer at Dian Nuswantoro University Semarang (20122019). To deepen his knowledge and insight, he decided to continue his doctoral education (S3) by taking the concentration of Halal Management at the Walisongo State Islamic University Semarang in 2017 and graduating in 2020 where his studies were financed by the Directorate General of Islamic Education, Ministry of Religion of the Republic of Indonesia through the Program Domestic 5000 Doctoral Scholarship.

Mila Sartika, SEI, MSI is a Lecturer at the Faculty of Economics and Business, Dian Nuswantoro University, Semarang. Born in Ujungpandang on May 26, 1985, completed his undergraduate education at the Islamic Economics study program at the Islamic University of Indonesia in Yogyakarta and then continued his master's degree in Islamic Studies at the same university. Started his career as a permanent lecturer at FEB UDINUS in 2013 to - Present.[MG22] 